\title{
COMMERCIAL ARBITRATION OR COURT APPLICATION OF COMMON LAW RULES OF MARKETING ?
}

\author{
Wesley A. Sturges.
}

Mr. Justice Holmes has referred to a "noble instinct of scientific curiosity to understand why we maintain what now is." "But," he adds, "most even of the enlightened reformers that I hear or read seem to me . . . to become rhetorical just where I want figures."'

- It is the purpose of this paper, first: to raise the question why, in the light of facts and figures, we have certain common law rules that affect the activity of marketing goods, and second: to ascertain to what extent these rules are, and may continue to be, what Professor Commons $^{3}$ calls actual "working rules" in the business community.

Suppose a shipper consigns provisions to $X$, who receives them on a term-credit, but refuses to pay the agreed purchase price on the due date. If the shipper considers court action in New York he should be advised that he cannot have a trial of the issues before the first of 1929 if the case is docketed at once (extraordinary cases advanced on certificates of special importance excepted). On January I, I924, according to figures of Mr. Justice Guy of the New York Supreme Court, ${ }^{4}$ the trial calendars of the New York Supreme Court contained over 27,000 untried cases. With the judicial machinery operating at top speed, and counting outside settlements and discontinuances, somewhere between eight and ten thousand cases can be disposed of in a year. ${ }^{5}$ The 1924 figures just quoted also show that the annual addition to the calendars is between ten and fifteen thousand new cases. This is the situation in New York while the taxpayers main-

${ }^{1}$ The principal part of this article was read at a round table conference of the commercial law section of the American Law School Association at its annual meeting at Chicago, December 29, r924. The conference discussed legal problems in marketing.

The writer wishes to make acknowledgment to Mr. John Caskey for assistance in collecting the facts set forth in this paper.

"Holmes, "Introduction, Rational Basis of Legal Institutions" (1923) Modern Legal Phil. Series.

${ }^{3}$ Commons, Legal Foundations of Capitalism (1924) 134, 140.

- Reported in New York Evening Post, Dec. I3, rg24.

${ }^{5}$ No extensive figures are available to the writer bearing on the ratio of cases taken off the records by outside settlement or discontinuance and cases carried through court action. The Superior Court of New Haven County, Connecticut, is reported to have disposed of 1505 cases during the year ending September I, 1924. Of this number 346 were discontinuances, 307 withdrawn without costs, 52 withdrawn after costs paid and 14 cases transferred to be heard in other counties. 
tain 35 Supreme Court justices, 30 Municipal Court justices and ro City Court justices.

In the United States Federal courts the congestion is similar. On June 30, 1924, cases waiting for trial in the United States Federal District courts on the civil docket, exclusive of bankruptcy, numbered fifty-six thousand thirty-two, and on the criminal docket, excluding cases under the draft, forty thousand two hundred and ten-a total of ninety-six thousand two hundred and forty-two untried cases. As for the Federal Courts of Appeals, the Court of Claims and Territorial Appellate Court figures are unavailable to the writer, but he is informed that the number of their untried cases is negligible. The Supreme Court had 462 cases pending on the above date. ${ }^{6}$

General consequences of this delay of trial coirts, which is experienced in varying degree in most, if not all, jurisdictions, are stated in the following seemingly rhetorical but, unfortunately, all too accurate summary: "rights suffer irreparable wrong; wrongs go unrighted; parties and witnesses die, scatter and disappear; evidence is lost or destroyed; memories fail and testimony loses its distinct value; frauds and perjuries evolve and are matured; insolvencies and bankruptcies intervene, so that when the tardy day of judicial trial drags the often seriously weakened case to the bar of justice, justice ofttimes cannot be had or is very ineffective."

Let us look at the shipper's position a little more in detail. If he must rely upon the courts to enforce his claim, the delay just mentioned indicates the minimum time that the purchase price will be idle capital

\footnotetext{
- For certain consequences of this pressure of cases, not elsewhere to bo particularly noted in this article, the following should be quoted from Dean Pound: "... the condition of pressure under which causes are passed upon in the American urban communities of to-day where crowded calendars preclude the thoroughness in presentation and deliberation in judicial study which were possible a century ago, prevents judicial law making from achieving its best. An example from the law reports will make clear what this means. In 4 Wheaton's Reports, reporting the decisions of the Supreme Court of the United States during the year I8I9, decisions in thirty-three cases are reported. In other words, seven judges decided thirty-three cases in that year. In 248-25I United States Reports, we may see the work of that court a hundred years later. In I9Ig the court wrote two hundred and forty-two opinions and disposed of six hundred and sixty-one cases. If we look only at the opinions written, where seven judges wrote thirty-three opinions in I8I9, nine judges wrote two hundred and forty-two opinions in rorg. . . . This does not mean merely that the judges are compelled to work rapidly and with a minimum of deliberation. In order to hear these cases at all the time allowed to counsel must be greatly abridged. . In state courts the pressure has become even greater. Thus at a time when constructive work of the highest order is demanded ... in many of our states the courts are none too well equipped to do the work effectively and in all of them the pressure of business is such that work of the highest type is all but precluded." Pound, The Spirit of the Common Laze (I92I) 8, 9.

'Wheless, Arbitration as a Judicial Process of Law (1924) 30 W. VA. L. QUART. 209.
} 
for the shipper and additional capital for the buyer. For our shipper it means the loss of gross-profit earning power. According to investigations of the Harvard Graduate School of Business Administration, Bureau of Business Research, the capital-dollar of a wholesaler of groceries and provisions has a gross-profit-earning-power ranging from a low of $7.7 \%$ to a high of $17.2 \%$-common, I2.0\%. A retail grocer's capital has a gross-profit-earning-power ranging from $14.6 \%$ to $27.9 \%$-common, $21.0 \%$. These figures are taken from a business where, due to highly competitive conditions, it is believed that the margin of gross profit is particularly low. ${ }^{8}$ For the delay period of the courts, our shipper is deprived of this gross earning power of the purchase price-the buyer has it.

But it may be suggested that when judgment is procured, interest, at the legal rate, may be allowed on the price from due date. Assuming this to be the rule-an assumption not entirely free from doubt and conditions according to the authorities-it will help some. ${ }^{9}$ However, this legal interest-rate is $6 \%$ in New York and in other states averages below $7 \% .^{10}$ So far as this allowance at such rates is supposed to reimburse the shipper for loss of opportunity to use the money as capital or to take from the buyer its capital-use-value to him, it appears to be an inadequate adjustment. On the other hand, it may be urged that this interest allowance is not "on the legal theory" of reimbursing for the capital-use-loss of the purchase price nor to take from the defaulting buyer its capital-use-value to him, but rather is "on the legal theory" of indemnifying the shipper for the interest which he must pay on that amount of further capital borrowed to replace the item in question. The validity of this theory depends upon the facts of the particular case. If his lines of credit were not already taken on the due date this legal theory is sound. If his maximum credit position was taken, obviously the allowance is on a fallacious assumption; it is then only a makeshift adjustment. Whether or not it was taken presents a question of fact. As a "long run" proposition, however, it may be suggested that if his enterprise is profitable the shipper would be using his maximum credit, for his way to profits is by business volume (assuming the enterprise is non-monopolistic). If the business is not profitable of course he is generally without commercial credit. Our shipper will refer to his books in this matter; the courts decide "on principle" - as a matter of law. ${ }^{11}$

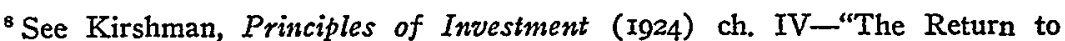
Invested Capital."

' 2 Sutherland, Damages (4th ed. Igr6) sec. 642 .

${ }^{10}$ In 6 states the "İegal rate of interest" is $8 \%$; in 7 states, $7 \%$; in 32 states, $6 \%$; in 3 states, $5 \%$. The rate for which parties may bargain in the different states varies much more.

${ }^{11}$ I Sutherland, Damages (4th ed. I9I6) sec. 76: "Money, like the staples of commerce, is, in legal contemplation, always in market and procurable at the lawful rate of interest; and the same principle which limits a disappointed
} 
Furthermore, we may refer to the loss consequent upon this delay of the law, which obtains in perishable and semi-perishable commodities where, for example, they are not accepted by the consignee. If both parties are obstinate and stick to their legal rights the provisions may rot. The New York Chamber of Commerce puts this loss in terms of "many millions annually." 2 While this statement is unaccompanied by any table of figures, it seems probable that some such waste does occur.

So far we have considered consequences of the "law's delay," as the aphorism goes, as if it ran only to a probable date of trial. But probabilities of extended trials, appeals, new trials and further appeals, and costs incident to employment of counsel, printing of records, commissions to procure evidence, are matters of common knowledge. Certainly the record to date in the Willett-Herrick case in Massachusetts is not out of place in this connection as indicating possibilities in trial court practice. Thirteen months (I87 days actual trial days) have been spent by the Norfolk Superior Court in Dedham in trying a claim for $\$ 15,000,000$. Testimony to the extent of 30 volumes of $35^{\circ}$ pages each was taken from 45 witnesses. There were 954 exhibits. One juryman was excused by consent of both parties on account of nervous breakdown. The remaining II returned a verdict for $\$ 10,534,109.07$. They did so within 72 hours. The jury consisted of four clerks. one stonemason, one printer, one railway employee, one carpenter, one machinist, one painter, one retired minister and one shoemaker. ${ }^{13}$

So far reference has been made to these costs, losses and waste, if they may be so described, apparently from the point of view of the entrepreneur, our shipper. But lest we appear to be worshipping at the altar of the great god Business, they should be traced, if possible, to their final resting place. Do they stop with the entrepreneur?

vendee's recovery against his defaulting vendor to the market value of the commodity which is the subject of his contract restricts the creditor to the principal and interest."

${ }^{12}$ A circular memorandum dated Dec. 20, 1923, sponsoring a Federal Arbitration Bill, Sen. Rep. roo5, House Rep. 646.

${ }_{13}$ The New York World of Dec. 28, 1924, makes this further report of the case: "The cost of the long trial, which had to be borne by the one city and twenty-seven towns of Norfolk County, is estimated at $\$ 50,000$. Of this the payments to the jurors for their thirteen months of service accounted for $\$ 20,000$. The stenographers cost $\$ 3,790$; the making of the transcript of testimony, $\$ 3,345$, and the salaries of the court officials, $\$ 5,605$.

What the cost of the eminent counsel retained by both sides over so long a period may total has not been revealed. But there is no doubt it has been an eminently satisfying case from the point of view of the bar and that its potentialities are by no means exhausted. Judge Callahan gave the attorneys almost six months, instead of the customary twenty days, to make up their bill of exceptions. It is hardly probable that a brief for the defense can bo prepared before Nov. I, I925, or that the Supreme Court of Massachusetts will reach a decision on the appeal much before Nov. I, I925. (?) So the case bids fair to run on for at least two years longer." 
Can the observation be made validly, that if they did, having regard for scales of net profits, that the entrepreneur function, as we now know it, would become defunct? That accounting technique carries these costs or losses on to the consumer will not be denied. That the process of marketing is fitted for that end will not be denied. That the consumer can bear it if he must is probably true. Whether he does or does not the writer can scarcely prove, so an answer to the question is left to inference. ${ }^{14}$

But what bearing do these data on the glutted conditions of the courts, and the question of costs and losses incident to delayed trials and protracted litigation generally, have to do with rules of the common law courts that affect distribution? It seems fitting in this connection to refer to that rule established by the courts which has effectively' disabled entrepreneurs from accomplishing a program of their own for adjusting their disputes arising in the market. Business men have devised such programs - the one most frequently recurring in evidence being that of arbitration. American courts have quite uniformly declared that any such general agreement is against public policy and invalid in so far as it undertakes to "oust the courts of justice of jurisdiction." ${ }^{\prime 15}$ This rule has always enabled one party, whatever his motive, to escape to the interstices of a common law court trial whether in former days they were found in the technical forms of action and vagaries of pleadings and proof and tactics of practitioners, or in modern days in congested trial calendars and some modern counsel still gallant with technicalities.

The formula of the rule has been, as stated, that as an agreement to "oust the courts from jurisdiction" it is invalid. In this doctrine American courts have been ruled from the grave of Vynior's Case decided in $1609 .{ }^{16}$ There, when the notions of agency were yet forming, it was resolved that "a man cannot by his act make such authotity, power or warrant not countermandable, which is by the law and of its own nature countermandable." The modern dress was not given to the dogma until Kill $v$. Hollister, ${ }^{17}$ where it was resolved by the whole court in a report of less than four lines that "if there had been

\footnotetext{
${ }^{14}$ In the circular memorandum of the New York Chamber of Commerce, supra note I2, appears the following statement: "The Bill (for a Federal Commercial Arbitration Statute) on the one hand, aims to eliminate friction, delay and waste, and on the other, to establish and maintain business amity and to reduce the price of commodities to the consumer; this latter on the theory that a merchant in figuring his cost adds to his price a certain amount representing the risk of rejection, claims, fault-finding, etc., even including litigation."

${ }^{10}$ To agree to arbitrate in such cases is valid in most states to the extent of imposing a duty to arbitrate, a breach of which will support an action for damages, nominal damages being awarded. See 3 Williston, Contracts (1921) secs. I'I9-I724.

${ }^{18}$ (I572) 8 Coke, Rep. 8rb. See Cohen, The Law of Commercial Arbitration and the New York Statute (I92I) 3I YALE LAw JoURNAL, 147; also Cohen, Commercial Arbitration and the Law (Ig18).

${ }^{x 2}$ (x746, K. B.) I Wils. I29, 95 Eng. Rep. 532.
} 
a reference depending, or made and determined, it might have been at Bar, but the agreement of the parties cannot oust this Court; and as no reference has been, nor any is depending, the action is well brought, and the plaintiff must have judgment." The English courts long ago effectively overcame the rule. ${ }^{18}$

In the light of the facts which have been reviewed concerning modern conditions, and with the history of common law actions and pleadings and their costs and delays in mind together with the origins of the rule as indicated, I will merely raise the question: what public policy is or ever was violated by business men agreeing to settle their commercial disputes in their own back yards ? $^{10}$ If an adjustment can be made at less cost, loss and waste, how will the consumer react? Whether business men generally desire to engage in such a program is another question, a question of fact to be considered later.

Let us turn to another rule, rather group of rules, with which the entrepreneur finds fault. He complains that these rules unnecessarily demoralize his enterprise as a going concern. He alleges that the courts in these cases appear to have the erroneous idea that every business transaction is vitalized by an assumption of the parties thereto that evidence is then being made for a future lawsuit between them.

Suppose that (at trial) our shipper is put to proof of the delivery of the goods. Records of a common carrier are not available. How shall he proceed under the law? The shipper explains that his books show shipment. He desires to use them for that purpose. He says that his books are accurately kept-he urges two reasons why: (I) that the clerks are anxious to maintain their efficiency rating, and (2) that in the modern business enterprise the management is so highly dependent upon its many employees that to instruct them in falsification of books would be business suicide. Our shipper explains further that the given items were only a portion of his.production volume and that it passed through the hands of many employees-through the warehouse of finished goods, through the inspection department, the packing department, another inspection department perhaps, through a shipping department and finally out into the hands of draymen. Various employees in the various departments accomplish some part of the accompanying record for the proprietor's "books." The

${ }^{18} 3$ Williston, Contracts (I92I) sec. I720; cf. Doleman \& Sons v. Osset Corp. [I9I2] 3 K. B. $257,68$.

${ }^{29}$ For' a searching criticism of the assignment of reasons for this rule see Hough, J., in. United States Asphalt Refining Co. v. Trinidad Lake Petroleum Co., Itd. (I915, S. D. N. Y.) 222 Fed. I006, I008: "It has never been denied that the hostility of English-speaking courts to arbitration contracts probably originated [as Lord Campbell said in Scott v. Avery (I855) 5 H. L. Cas. 8II]in the contests of the courts of ancient times for extension of jurisdiction-all of them being opposed to anything that would altogether deprive every one of them of jurisdiction.' A more unworthy genesis cannot be imagined. Since (at the latest) the time of Lord Kenyon, it has been customary to stand rather upon the antiquity of the rule than upon its excellence or reason: ...." 
"books" show the course of the items and their "clearances" from one operation and department to another. Of course the employees took no special notice of these particular items which passed in the routine of production some four or more years ago if the case is at trial in New York (probably a lesser period elapses in most state courts). But are his books so admissible in evidence on this issue of delivery? There are some long standing principles to consider first before the question can be answered. These principles originated several hundred years ago but shall they be discounted because of changed conditions? What are these principles? (I) That testimonial evidence must be by the person who saw and knows-a "hearsay rule" demands this, subject to exceptions. (2) The right to cross examination of a witness under oath must remain inviolate. But there are exceptions to these principles. For example, a witness with no present recollection of past events may employ a record correctly made by himself substantially contemporaneously with the event to revivify recollection of the event, or to "refresh his memory" as the expression goes. This exception, according to cases cited by Mr. Wigmore, rests on the principle of necessity. Apparently we are now approaching close to the question at hand in the process of color-matching. If in legal theory the above exception is valid, certainly our shipper's books are admissible with the testimony of the clerks who made the entries-and the cases are to this effect. "But," says the shipper, "must all of my employees appear? This event happened several years ago. My employees never had vivid impressions of these items, and they have certainly faded since the day. Some of them are no longer in my employ and I do not know their whereabouts. Some who doubtlessly made parts of these records have been promoted; others have been reassigned according to their particular adaptation since we had the psychological tests; others are dead. I doubt if I can ascertain which part of the records were accomplished by any particular employee." What is the answer? The decisions are in notorious chaos. In some jurisdictions in some of their cases it would appear that the books may be entered by the principal officer in charge of the accounts; in other cases in many of the same jurisdictions, as well as in other states the clerks must appear en masse, and having been duly prompted as to which part of the records they accomplished, are to testify as to what happened years ago concerning the items in question. Of course handwriting may help, assuming that they did not go to business college and learn the same system of handwriting. If some of the clerks are dead, or insane, or by some cases if they are not readily available in the jurisdiction, some courts are more readily inclined to strain principles and admit the records, other courts are quite as obstinate as in other cases. I refer to section 1530 of Mr. Wigmore's work on Evidence for a monument of patient labors with the confusion of decisions both with and without statutory provisions being involved..$^{20}$

\footnotetext{
${ }^{20} 3$ Wigmore, Evidence (2d ed. 1923) sec. 1530.
} 
"Lastly," urges our shipper, "even if all of my available employees who had contact with my books must go to court, certainly it is permissible to have made authenticated copies of material portions of the records so that the originals will be left in the shop for current use." Of course our shipper is entirely too naive' on this point. Books, the originals, must go, and go complete-the "best evidence rule" is mandatory, and it makes no difference whether the trial lasts one day' or extends over a period of thirteen months perhaps. In the business community this aspect of administration of the law is irritating indeed. There an enterpriser's books have validity, they serve as the basis of business enterprise and calculations (specifically, reference may be made to credit insurance)--even the tax collector is credulous respecting them.

In this connection I will cite the following experience of a $\mathrm{New}$ York firm of lawyers substantially as it is reported.21 Defendants were sued on a guaranty of a bill of goods sold by plaintiff to $\mathrm{X}$ corporation, of which defendants were officers. The corporation admitted delivery and had given notes. But defendants' counsel made the usual denial of knowledge. Plaintiff was obliged to gather up a score of former employees in a New Jersey factory since abandoned, to bring on others from his Pennsylvania factory and spent two days in proof of what every one knew to be a fact. Continuing the report: during the course of the trial defendants' counsel discovered one order out of more than one hundred that had been manufactured by plaintiff in his Kentucky factory. Plaintiff abandoned its claim of between six and seven hundred dollars rather than bring on the necessary Kentucky employees and records. 'Compare the English practice where in absence of affidavit of non-delivery by defendant's counsel, and satisfying the court that a real dispute obtains regarding delivery preemptory judgment goes for the plaintiff on the point.

Let us take another case. Suppose that our shipper finds that a letter written by him to the defaulting buyer will serve his side of the case. He has a copy and is confident that defendant received the original, but how prove it?

I again quote from Mr. Ehrich (cited above) who has had experience with this matter in New York: "The law requires that before the letter can be admitted in evidence, it must be traced to the mail chute, letter box or post office. The sender must call the secretary whose duty it was to take the letter from his desk and the office boy who stamped and mailed it and have them testify that they performed their duties on that day as on every other. If the secretary and office boy are still in the employ of the sender and the office is in the vicinity of the court house, the matter is merely tedious and stupid. Actually, however, lawsuits are not generally anticipated. When they do arise they often involve transactions dating back for many

\footnotetext{
"Ehrich, Unnecessary Difficultics of Proof (1922) 32 Yale Law JouRnal,
} $436,437$. 
years. Of course if the secretary and office boy are available, they will testify that as far as they remember they performed their duties on the particular day as on every other day. Presumably the letter was mailed. If it was mislaid by oversight, neither the office boy or secretary would be aware of it. If one of them suppressed the letter deliberately and fraudulently, apparently he would, no doubt, hide his guilt. If the letter was written only to make a record and then suppressed, that purpose could easily be accomplished without their knowledge." 22 If the office boy or secretary or both are dead, they need not testify. If their unavailability. is for cause short of death, the rule appears to have a confusion of exceptions in the various states as to when their testimony may be dispensed with.

But assuming that the employees are at hand, have been discovered again, or that their testimony can be dispensed with under an exception to the rule requiring their presence, I will quote from a Georgia case of recent date for a prescription of the circumspection with which one must walk in some jurisdictions to prove that the letter was "mailed." The witness testified that he "mailed" the letter. The opinion of the court follows: "There are some authorities which hold that the word 'mailed,' when used in reference to sending matter through the mails of the United States carries with it the presumption that the postage due on such matter has been paid. But in National Bldg. Assoc. v. Quin (Ig04) I20 Ga. 358, that meaning does not seem to be given to the word 'mailed,' it being there used to describe the mere act of depositing a letter in the mails. In this sense there might be such a thing as the mailing of an unstamped letter. . . . There was evidence that at least one of the letters was properly addressed and that both were deposited in the mail, but the evidence is silent as to whether they were duly stamped."'23 Although the court states that "the presumption that a letter has been received when intrusted to the mail for delivery arises from the regularity in the method of business adopted by the postal authorities," it seems to have been more concerned here in defining the word "mailed" than in referring to further postal regulations, which are here assumed to be generally known, adopted to assure delivery of the unstamped letter to the addressee or return thereof to the sender. Perhaps, however, we should say that counsel were at fault for not "laying proper foundations."

Further consideration of the rules of law affecting business correspondence will not be undertaken. Reference may be had to $\mathrm{Mr}$.

\footnotetext{
- Supra note 2I, at p. 440 .

${ }^{23}$ Bankers' Mutual Casualty Co. v. People's Bank (1907) I27 Ga. 326, $56 \mathrm{~S}$. E. 429; W. T. Raleigh Medical Co. v. Burneycal (IgI8) 22 Ga. App. 492, 96 S. E. 578. See also Welsh v. Chicago Guaranty Fund Life Society (1899) 81 Mo. App. 30, 36; Glaser v. Williamsburg City Fire Ins. Co. (Ig20) 72 Ind. App. 319 , I25 N. E. 787. Contra: Oregon Steamship Co. v. Otis (1885) 100 N. Y. 446,3 N. E. 485 ; City of Onaha v. Yancey (IgI2) 9I Neb. 26r, I35 N. W. I044; Brooks, Boardman \& Ford v. Day (1860) II Iowa, 46; Tozm of Bamet $v$. Towm of Norton. (I9I6) 90 Vt. 544, 99 Atl. 238.
} 
Ehrich's article already cited and quoted at length. One cannot refrain, however, from reviewing Hazvley v. Whipple (I869) 48 N. H. 487, which appears to recite the orthodox limitations prescribed by the courts for proving telegrams. It became material for the plaintiff to prove that a telegram was sent by one Gould in Montreal to plaintiff in Northumberland, N. H. Plaintiff sought to show this by a reply telegram purporting to come from Gould following soon after a telegram sent by plaintiff to Gould in Montreal. The reply was apparently satisfactorily understood and acted upon by plaintiff. Held, properly excluded. The court says: "Now it is claimed that, as in case of a letter, so in case of telegraphic dispatches the person who answers a dispatch is so generally and uniformly the person to whom the communication was addressed that it may be safely acted upon, and that it is thus acted upon in all business arrangements of the country. But there is a difference in principle between the two cases. . . it results from the fact that the messages are first written by the sender, and are again written by the operator at the other end of the line, thus causing the inquiry as to which is the original. The original message whatever it may be must be produced, it being the best evidence; and in case of its loss ... the next best evidence . . . It will be seen at a glance that there is nothing about the handwriting here that could indicate that the message came from Gould . . . This message might be received as it was sent, and would ordinarily be acted on in the business of life, but the only way to prove such a message in a court of law would be to summon both the intermediate agents or hearers of the messages, and in that way trace the message from the lips of one party until it was received in the ears of the other party. Anything short of that would be to rely on hearsay evidence of the loosest character."24

From this review of these cases it appears that the so-called "hearsay" rule of evidence and the "best evidence rule" are strongly entrenched, business practice and costs to the contrary notwithstanding. Taking account of what truth their application secures in these cases, and comparing it with the costs and rupture of business which they cause, I merely leave the question whether the administration is economical - whether it is worth while? And again I will voice the question whether, if there is undue cost or waste, the process of distribution, marketing, carries it on to the consumer; or does it stop with the entrepreneur?

- The last complaint of the business community which arises in connection with the activity of marketing to which reference will be made is the misfit with business policies of what I will call the "standard equipment" of the common law courts for enforcing legal rights. The

"4 (Italics mine.) Accord Cobb v. Glen Boom \& Lumber Co. (1905) $57 \mathrm{~W}$. Va. 49, 49 S. E. 1005; cf. Showalter v. Chambers (I9I6) 77 W. Va. 720, 88 S. E. 1072; 4 Wigmore, Evidence (2d ed. I923) sec. 2I54; Ehrich, op. cit. supra note $2 \mathrm{I}$, at p. 444 . 
attachment or execution process of a common law court strikes where it may in the effects of the debtor (statutory exemptions excepted). It exacts the pound of flesh regardless of consequences to the debtor as an economic or business unit in society. The execution takes no account of the debtor's future as a going concern. If a retailer, for example, becomes embarrassed the common law court rules a "race of diligence" for the vitals of the enterprise.

If it is urged that equity receiverships are available in such cases whereby the enterprise can be taken under court control and preserved as a going concern and creditors' claims liquidated without chaos, we may admit the statement. If we look at figures, however, the statement may lose some of its importance. A survey made by the $N e w$ York World of two hundred thirty-three cases of Federal Equity Receiverships in the Federal Courts of New York, Southern District, during their operation from January I, I9I7 to December I, I923, disclosed the following information bearing on the success of the program. Although the concerns were taken over as alleged solvent concerns, chiefly embarrassed in their ratio of current liabilities to current assets: (I) In only I5\% of the two hundred thirty-three cases did the general creditor get payment in full in either cash or securities of a reorganized company. (2) Thirty-five of the two hundred thirtythree concerns were reorganized and put back into private operation. The rest had been, or were being, liquidated at the date of reporting the survey. (3) In twenty-six cases the general creditor got nothing although there were assets sufficient to pay administration expenses in those cases to the amount of $\$ 234,000$.

Where did the administration costs go? The total allowances and disbursements authorized and made up to December I, I923 in the two hundred thirty-three cases studied were $\$ 7,695,498.46$, allocated as follows:

(a) To Receivers . . . . . . . . . . $\$ 3,405,086.96$

The receivers in most of the cases were attorneys-and so far as appears the business executives were still retained on the pay rolls.

(b) Attorneys to the Receiver or Receivers (in some cases more than one receiver was appointed ) . ............. \$2,6ro,636.83

(c) Other attorneys .............. 883,780.82

(d) Special trustees .............. I 5 I,73I.49

(e) Appraisers, auctioneers, accountants, engineers . . . . . . . . . . $644,262.36$

If the machinery of the bankruptcy court is set in motion the "legal expenses" of liquidation are notorious.

Thus far I have considered three sources of complaint with our common law courts which come from the business community: ( $I$ ) That the courts are too glutted with untried cases and their procedure 
always has been too slow and hazardous with technicalities to warrant obstructing or taking the "teeth" from programs of business men, such as arbitration, to adjust their own commercial disputes. (2) That the rules discussed are too expensive, wasteful and devoid of convenience. (3) That there is lack of adequate and economical technique to adjust rather than "bust" the going concern. ${ }^{25}$

With this background taken from experience let us look at our second general question: Are the foregoing rules of the common law courts the actual "working rules" in the business community? Are they the rules that concern the entrepreneur throughout the business week or are they invoked only on an extraordinary occasion when vengeance is to be had? If such have been the working rules to date, is there promise that they will continue to be such in the future?

Let us first notice a few programs that are practiced in the business community to prevent waste of the debtor as a going concern: (I) In the case where banks are creditors it is deemed to be too well known to require evidence that it is their practice to "nurse along" (as has been stated to the writer) the honest but embarrassed debtor whose future may be sufficiently promising. It appears to be their policy further to wield their economic power- to induce outsiders to comply with such programs in lieu of their strict legal rights. If the debtor is to be "wound up" it will be by settlement-agreement if the bank is a sufficient creditor to control. It appears to be the opinion of bankers that a creditors' committee functioning outside of the bankruptcy court is generally more expeditious and less expensive than bankruptcy court administration. Whether the banks should have the big stick, or whether they should wield it are questions which are not here considered. ${ }^{26}$ I am merely undertaking to state facts to indicate what are some of the working rules in the business community.

We may refer briefly to another manifestation of the same program. I refer to wholesale grocer associations sponsored by the National Credit Men's Association. I will mention the New Haven Branch. The New Haven wholesalers are associated for their mutual protection in their dealings with retailers, and with respect to outsiders. The secretary is a "tickler" on the credit standing of the retailers. If a retailer becomes financially embarrassed and an outside creditor dips into the business with an attachment and is insistent upon his legal position, his claims may be purchased if the debtor and his business prospects warrant. If not, he will be liquidated, normally in the bankruptcy court. The writer is informed that there are two or three of such cases annually. On the other hand, if the wholesalers alone

\footnotetext{
${ }^{20}$ If it has been concluded that the process of marketing carries the costs and wastes to the consumer, still the entrepreneur has cause for complaint which is more than for mere inconvenience. That he bears the interim risks of passing on the losses to the market would not be denied.

${ }^{\infty}$ It is not intended by so passing over the subject to minimize its importance. See, Frankfurter and Landis, Bankers and the Conspiracy Law (Jan. 2r, I925) NEW REPUBLIC, 2I8.
} 
are involved, or can control the situation, the writer is informed that their practice is to "carry him along" and let the retailer work out his indebtedness in his business under such creditor supervision as may be prescribed. In this connection I will quote from the by-laws of the Association: "Paragraph II. The Object: The object of this organization shall be to protect and promote the financial interests. of its members by' preventing failure when possible and by co-operating in. bankruptcy cases in which its members are concerned, and it is understood and agreed that in case attachment or other proceedings are necessary locally for the protection of the assets of any debtor, such action shall be taken through the attorney of this organization for the benefit and in the interest of all members of the organization."27

A similar, but more comprehensive, program is likewise sponsored by the National Credit Men's Association. In eighty-five commercial centers, located in thirty-five states and the District of Columbia, the association has organized what are called Adjustment Bureaus. The aims and objects of these bureaus are set forth in part, as follows:

"I. To investigate, upon request, the affairs of a debtor reported to be insolvent and to adjust the estate, when possible, without court proceedings.

2. To secure capable and efficient receivers, appraisers, or trustees when court proceedings are found to be necessary.

3. To secure quick adjustment of all honest failures at the minimum cost and with the maximum dividend to creditors." 28

Concerning the efficiency of these bureaus the following is quoted from a recent writer on the subject: "It is but natural that insolvent estates should be liquidated to better advantage by creditors than by a court and individuals who have nothing at stake. Adjustment bureaus usually have skilled appraisers and competent attorneys and merchandising men to place in charge of the affairs of insolvent debtors. In addition, they keep in touch with special avenues through which merchandise inventories can be disposed of regularly to greatest advantage. The charges seldom exceed 7 per cent. of the amount distributed as dividends, except where special services of an unusual character are rendered. Average returns to creditors from friendly liquidations conducted by the bureaus compare very favorably with amounts secured through bankruptcy proceedings, the former varying from 50 to 60 per cent., whereas the latter approximates 25 to 30 per cent. on the average. In many instances, dividends distributed by the bureaus have amounted to the full amount of the claims. Even in bankruptcy cases the presence of the bureaus has resulted in higher dividends and in more economical administration." 29

\footnotetext{
${ }^{27}$ By this paragraph it is understood that priorities gained by any member's attachment shall be waived in the interest of all the members.

${ }^{29}$ (1906) Bulletin, National Association of Credit Men.

${ }^{2}$ Beckman, Credits and Collections in Theory and Practice (I924) 389, 390. At p. 39I the author cites the following case handled by the Adjustment Bureau
} 
These programs would seem to indicate a purpose of the business community to preserve distributing or marketing units as going concerns if feasible; otherwise to liquidate by non-court action. They appear to be in substitution for strict legal rights. That a given program is motivated by selfish interest of the banker, wholesaler or manufacturer is a plausible inference. The purpose at hand, however, is merely to point out the existence of the programs.

Finally, what is going on in the business community, if anything, to ward off the losses of commercial litigation as they appear to obtain in the common law courts ?30 I will merely enumerate some facts bearing upon the development of commercial arbitration. Although in several trades it has been the accepted program. for adjustment of intratrade disputes for a considerable time (in the silk industry, for example, since 1898 ) the program has gained most momentum with the procurement of the New York Arbitration Statute which became effective in New York April I9, I920. After no little expenditure of time, effort, and money, the New York Chamber of Commerce, urged on by the London Chamber of Commerce, procured a statute declaring "a new public policy" in New York whereby the dead hand of $V y$ mior' $s^{31}$ case was vanquished. The statute nullifies the legal power of parties to break their agreements to arbitrate. Since that time the program has spread rapidly. Of the larger aspects of the program I will refer to the following. In June, I923, the New York Merchants Association circularized about one thousand commercial firms in the City of New York to pledge themselves to insert an arbitration agreement in their commercial contracts. Eight hundred seventy-nine agreed to do so; four refused, principally on the ground that they never had any lawsuits. As to subsequent developments in that organization I have no figures. There has also come about the organization of a New York membership corporation,. The Arbitration Society of

of the Chattanooga Association of Credit Men. There were 482 creditors, many of whom lived at a distance; their claims against an insolvent aggregated $\$ 220,701.68$. The writer concludes: ". . . the liquidation ... involved an expenditure on the part of the bureau of 2 per cent. of all claims, the case was kept out of the courts, and the creditors have already received at the time of this writing 65 per cent. on their claims."

${ }^{30}$ The amount of these losses has been stated as follows: "The aggregate economic loss to the nation through the necessity of referring to courts the trial of disputes arising in the course of trade would stagger imagination if it could be accurately computed both as to actual cost and to the indirect drain upon national resources. Next to war, commercial litigation is the largest single item of preventable waste in civilization. The physical inability of the organs of legal machinery to cope with the mass of litigation that is waiting for adjustment; the costliness and elaborateness of proceedings; the latitude that permits unscrupulous litigants to defer final judicial action at an incalcuable injury to honest business-all these elements combined form so great a handicap to the prompt and economic administration of justice as to defeat its ends in many cases." Commerce Reports of Oct. 13, I924 (published by the Bureau of Foreign and Domestic Commerce) 67 .

"Supra note I6. 
America, the present membership of which is made up of over twelve hundred firms which are in or near New York City or have representatives in New York City. ${ }^{32}$ Membership dues are devoted primarily to "selling arbitration" to the business community of the country. Its representatives are now engaged in installing standard contracts with arbitration provisions therein in something over one hundred separate trades in and about New York City. The Society also affords arbitration facilities for its own members and outsiders.

But promotion of the program is not localized to New York. The New York statute has been copied in New Jersey. Again, sponsored by more than one hundred twenty-nine Chambers of Commerce, Boards of Trade, producers, wholesalers' or retailers' associations throughout the United States, a Federal bill, copied in general after the New York statute and affecting interstate and foreign trade and commerce, has been introduced into the United States Senate and House of Representatives. Further, a Uniform State Arbitration Act has been drafted by the Conference of the American Bar Association on Uniform Laws. ${ }^{33}$

How is the program working where it has been tried? As for the Arbitration Society's tribunal which has been actively functioning as such for less than one year, over five hundred cases have been adjusted. The writer has been informed that only one case has. been discovered where the award has been attacked in court. The Secretary of the Committee on Arbitration of the New York Chamber of Commerce has reported on the program as follows: "Our experience with the arbitration of claims has been a rather curious one. It is that the arbitration clause not only prevents litigation but also arbitration, and as such it represents a remedy which works both ways satisfactorilypreventive as well as curative. This experience has been duplicated

so The membership includes such concerns as: American Sumatra Tobacco Co., B. T. Babbitt \& Co., Doubleday, Page \& Co., Fidelity and Casualty Co., Huyler's, and Moody's Investors' Service.

${ }^{3}$ The writer is informed by Mr. William E. Britton, a member of the Committee, that the proposed Act will be reported to the American Bar Association for consideration at its 1925 meeting. The Act is drafted along the lines of the New York statute, except that the agreement to arbitrate is irrevocable only when made with respect to "any controversy existing between them at the time of the agreement to submit." This is copied from the Illinois law. By the New York and New Jersey statutes, and in the Bill introduced into Congress to provide for a Federal Arbitration statute, such arbitration contract is irrevocable and refers to "a controversy thereafter arising" as well as to "a submission hereafter entered into of an existing controversy." It appears to be the sense of the Committee that to make the agreement to arbitrate irrevocable with respect to future controversies arising out of the transaction would work injustice upon such business men as might sign an agreement not knowing that it contained an arbitration provision. Such position is not immediately plausible. It should be determined on evidence whether modern business men need such protection against themselves. The assumption that "more justice" is available from the orthodox commercial lawsuit than from an arbitration should also be supported by fact. 
by the Manchester (England) Chamber of Commerce."34 But does it? I will only quote the following report of the general counsel of the Moving Picture Industry:

"Fourteen or fifteen months ago we started to put into effect arbitration. There were first organized in thirty-one key distributing centers of the United States, in thirty-one cities (I will not stop to name them), Film Boards of Trade, composed of the Branch Managers of each distributing company doing business in that particular city. Each of these Film Boards of Trade selected or elected three Managers of three companies, alternating from time to time, to sit upon an Arbitration Board, composed of six members for that key distributing center. The other three members were selected by the exhibitors or theater owners of that same distributing zone in like manner, and these six men constituted the Arbitration Board with the provision for and the right to select a seventh arbitrator or an umpire in case of a tie vote. Thirtyone of these Arbitration Boards in these same thirty-one key distributing centers, wherein are located the thirty-one Film Boards of Trade, were thus constituted.

"A Uniform Exhibition Contract was agreed upon by many of the distributors, and I think I am conservative in saying that today nearly all distributors of motion pictures are using contracts providing for arbitration, and probably ninety per cent. of the contracts that are being written today contain these uniform provisions for arbitration. There has naturally been some speculation as to what figures will be shown as the result of arbitration in this "infant industry" for its. first year, ...

"During our first year of arbitration (or to be a little more accurate, one Board is about ten months old, some are eleven months, one year, thirteen and fourteen months because they were not all organized on the same day, but approximately a general average for one year), these Arbitration Boards have heard, decided and disposed of more than five thousand cases. The figures of the New York City Arbitration Board alone show more than five hundred cases disposed of during this period of time. I am referring now to cases actually heard and disposed of by Arbitration Boards and not the number of cases that were disposed of by reason of the fact that both parties to our contract were obligated to arbitrate, brought into touch with each other, encouraged to sit down calmly and discuss their difficulties-and I may say here that three or four times as many casès, probably five times as many cases, were disposed of in this manner before they were actually brought before the Arbitration Boards, than were disposed of by Arbitration Boards themselves. The percentage of unanimous decisions in these five thousand cases was a fraction better than ninety per cent. In less than ten per cent. of these cases the votes were five to one or four to two, and in twenty-one cases only in the United States-

\footnotetext{
"Charles L. Bernheimer, Chairman Committee on Arbitration, New York Chamber of Commerce, in a letter of Dec. 3, I 924 to the author of this article.
} 
although we have no provision for appeal and arbitration decisions are final-in twenty-two cases only was the seventh arbitrator called in, and five of these cases were in the City of New. York.

"The money savings in distribution costs during this period of time can be most conservatively set at one and one-half million dollars."

"The industry has only two lawsuits pending in the United States."

An enumeration of the specific advantages which are claimed for the program may be added:

I. The program is inexpensive:

For the silk industry the Silk Association of America maintains an Arbitration Committee and tribunal primarily for arbitration of intra-trade disputes. Its by-laws provide that "each arbitrator's fee shall be \$ro a sitting and the award shall decide who shall pay the expenses and fees of the arbitrators." If both parties are non-members "a charge of $\$ 25$ will be made for the arbitration services of the Association" in addition to the arbitrator's fees.

The American Spice Trade Association provides for an arbitration tribunal primarily for intra-trade. disputes. The Arbitration Committee is elected by the members of the Association to adjudicate controversies and the committee "shall receive no remuneration, fees, or consideration whatever for their services."

In the New York Building Congress an arbitration tribunal is provided with provision for arbitrators' fees as follows: "If they are to be paid, a stipulation of the amount must be made at the beginning of the hearing." A fee of fifty dollars is required "for arbitration in the arbitration court of the Congress . . . to be borne equally by the parties."

The Arbitration Society of America charges the parties ten dollars for the use of a room and leaves the arbitrator's fees to bargain between the parties. In a case before that tribunal, with which the writer is familiar, a Chicago manufacturer asserted a claim of ten thousand dollars against a New York jobber. The latter alleged a counterclaim of over forty-five thousand dollars. The arbitration costs amounted to ninety-five dollars for each party. One hundred fifty dollars of this went to one arbitrator; the other two were business men who charged nothing.

2. The program is convenient for the parties in interest:

In the case last referred to the arbitration proceedings were set for a date that would meet the convenience of the Chicago man who at that date was to be in New York in his regular course of business.

In an arbitration of a dispute arising out of a building contract, proceedings were had on Saturday afternoon for the accommodation of a large number of sub-contractors who were parties in interest.

\footnotetext{
as Taken from the report of an address before the Arbitration Society of America in New York City, May 6, I924.
} 
3. The program is expeditious:

In no case of arbitration of a commercial dispute which has come to the notice of the writer has the trial lasted more than six hours.

In the Chicago case above referred to the dispute between the parties appears to have developed on or about November I6, I923. The case was arbitrated and settlement made according to the award on March 20, 1924 .

In a case arising between a New York distributor of moving picture films and an out-of-the-state exhibitor, a dispute concerning a four thousand five hundred dollar balance of a contract involving nearly seventeen thousand dollars, was adjusted by the New York Film Board within three weeks after it arose.

4. The program is simple of administration:

Parties generally appear in their own behalf. Rules of evidence are administered according to the understanding of the business community. Books of account have their business standing. The arbitrators are chosen by the parties because of their technical training and familiarity with the business out of which the subject matter of the dispute arises. Matters of technical detail need not be proved at the trial. In a case with which the writer is familiar, the seller was an Iowa packer; the buyer a New York City retailer. Seller delivered to buyer frozen beef tongues which were later discovered to be non-edible. Seller claimed purchase price. Issue: Were the beef tongues edible when delivered? The arbitrator who was chosen was an expert in the meat business. He procured in advance of hearing certain certificates of inspection of this meat executed at various times and places by various Federal inspectors as required by the United States Department of Agriculture. These certificates appeared to be controlling evidence as to the quality of the beef tongues when received by the buy'er. ${ }^{36}$ The arbitrator "knew how," and presumably saved time and expense.

5. The program tends to preserve good will among the disputants:

It is believed that the following excerpt from the letter of the seller to the buyer in the beef tongue case above cited is typical of the business man's valuation of the program: "In our conversation in your office of the tenth instant you expressed yourself as being agreeable to arbitration of the matter, and to get it over with in a friendly way. We suggest that we make use of the Arbitration Society of America, whose offices were at II5 Broadway, New York City. We are informed that they handle all the details, make all the arrangements, and - put the business through in proper form and with dispatch, and the entire cost to each party of the controversy is only \$10.00." This letter was written on June I3, I924; the case was arbitrated on August

${ }^{36}$ For the liberal view of the New York Supreme Court toward similar action by the arbitrator see Berizzi Co. Inc. v. Krausz (I924, Ist Dept.) 208 App. Div. 322, 203 N. Y. Supp. 442. 
5. I924 with costs, to each party of twenty-two dollars fifty cents, the arbitrator's fee being twenty-five dollars. The claim was for $\$ 238.76$.

6. The program assures such privacy of trial as the parties may desire:

In disputes, for example, which have concerned alleged defaults of practicing physicians in cases involving women patients, this advantage of the program has been attractive.

This advantage, together with elimination of costs and delays incident to court litigation-to say nothing of a community psychology that lawyers can no longer "exploit" the laymen-are apparently bases for reason to expect considerable development of this program in adjusting disputes other than intra-trade disputes.

The dub the program as one of "radicals" is is little short of ridiculous. If the judical system of the political state is now in competition with another system devised by merchants let marginal utility determine their relative values. Conceivably the legal profession will be instructed in the economic status of its existence. ${ }^{38}$

This program is of particular importance in appearing just at the time when judges and lawyers are engaged in a "restatement" of the law as that term has been defined. The question directly arises: Can the judicial system of the political state and the legal profession maintain their position even with many present rules of law "restated" ?39

\footnotetext{
${ }^{37}$ See Levy, Prompt Trial of Cases without a Jury (Feb. 5, I925) N. Y. LAW JOURNAL.

${ }^{33}$ The following is quoted from (Jan. 1925) 2 Arbitration News, 2:

"In a case decided by Supreme Court Justice Wagner early in the current month [Matter of Kayser (Skulnik) N. Y. L. Jour. (Jan. 14, 1925)] one of the parties to an agreement to arbitrate refused to appear before the Arbitrator unless his legal counsel also was permitted to appear with him, and a motion was made to compel his appearance with books and records and unrepresented by counsel.

In making its decision, the Court said in part:

'This presents for the first time in the courts of this state, so far as research has been able to enlighten me, the question whether parties to an arbitration may have counsel represent them as a matter of right. $\mathrm{My}$ view is that whether counsel may be heard or participate in the arbitration proceedings rests entirely in the sound discretion of the arbitrators. The very purpose of arbitration is to obtain inexpensive, expeditious and final determinations of disputes on the merits, free from technical rules and legal formalities. As a rule arbitrators are laymen, unacquainted with legal principles and procedure. The presence of counsel fortified with 'that wilderness of single instance' and with legal maxims and some legal anachronisms would tend rather to confusion and protraction than prompt decision. Besides, if one side employs counsel a burden is cast on the other to do likewise, with resulting added expense. To permit participation by counsel as a matter of right would be fatal to the efficacy of arbitration. Motion is granted. Settle order on notice.'

Under the rules of the Arbitration Society of America, lawyers may participate in arbitrations either as arbitrators or as the representatives of disputants. Every disputant under these rules has the right to be represented by counsel if he so desires, although his lawyer must conform to the strictly non-technical procedure in letter and in spirit."

Since this article was set in type, it has been reported that the Federal arbitration bill has been unanimously passed by the Senate and House of Representatives with the unfortunate amendment that it applies only to controversies in excess of $\$ 3,000$. New York World, Feb. I5, 1925, p. 2.
} 